Revista da Faculdade Mineira de Direito $\mid$ v.21 N.41 76

\title{
DA FORMAÇÃO DO ENUNCIADO CRIMINOLÓGICO À PRODUÇÃO DOS CORPOS INFAMES NA VIA DO JORNALISMO POLICIAL: RESSONÂNCIAS NA ESFERA SÓCIO-JURÍDICA
}

FROM THE FORMATION OF THE CRIMINOLOGICAL STATEMENT TO THE PRODUCTION OF THE INFAMES BODIES IN THE WAY OF POLICE JOURNALISM: RESONANCES IN THE SOCIO-JURIDICAL FIELD

Renata Celeste Sales ${ }^{1}$

Faculdade Damas - PE

\begin{abstract}
Resumo
A pesquisa teve por enfoque averiguar de forma analítica aspectos da esfera criminológica a partir da matriz filosófica de Michel Foucault. Em termos centrais o texto aborda a questão da formação e reconhecimento da figura do criminoso através da mídia policial e a interface na esfera social e jurídica criminal. A trajetória do texto buscou identificar a produção de "corpos infames" nas estruturas de saber-poder criminológicos. Nessa ordem, o problema enfrentado no trabalho consiste na observação do processo de formação do "enunciado de poder criminológico" a partir das narrativas do jornalismo policial.
\end{abstract}

Palavras-Chave

Enunciado criminológico. Jornalismo policial. Corpos infames.

\section{Abstract}

The research focused on analytically analyzing aspects of the criminological sphere from the philosophical matrix of Michel Foucault. In central terms the text addresses the issue of the formation and recognition of the figure of the criminal through the police and the interface in the social and legal criminal. The trajectory of the text sought to identify the production of "infamous bodies" in criminological knowledge-power structures. In this order, the problem faced in the work consists in observing the process of formation of the "criminological power enunciation" from the narratives of police journalism.

Keywords

Criminological statement. Police journalism. Infamous bodies.

\section{Introdução}

\footnotetext{
${ }^{1}$ Professora do Programa de Pós Graduação em Direito da Faculdade Damas da Instrução Cristã. Doutora e Mestre pela UFPE Líder do grupo de pesquisas "direito, biopolítica e subjetividades".
} 
Revista da Faculdade Mineira de Direito $\mid$ V.21 N.41 77

O presente artigo teve como ponto de partida uma análise do circuito criminal à luz da filosofia foucaultiana. Toda a cartografia do texto buscou identificar e comprovar a existência de "corpos infames" nas estruturas de poder e, sobretudo, nos espaços de saber-poder criminológicos. Ponha-se em relevo que os temas clássicos do saber-poder criminológico, como é o caso, por exemplo, da relação entre o monitoramento e a punição, somente obtiveram sistematicidade a partir da obra de Foucault ${ }^{2}$. O que nomeio de "corpos infames" no trabalho traduz uma interpretação de conceitos apresentados na obra foucaultiana como "sujeitos assujeitados" e "corpos dóceis", passando por uma observação do conceito de "vida nua" na obra de Agamben e ainda a intuição teórica do que a filósofa Judith Butler chama de "corpos abjetos". A intenção esteve expressa em demonstrar a existência dos "corpos infames" enquanto vidas descartáveis e, portanto, enquanto alvo de controle biopolítico. E, nesse sentido, apresentar a mídia enquanto vetor de controle e formação da imagem do delinquente no circuito penal.

$\mathrm{O}$ investimento de poder sobre os infames justifica-se em um duplo movimento, primeiro pelo caráter político de ameaça, risco e contraprodução que esses corpos podem representar. Depois, de modo paradoxal, são os "corpos infames" e a produção de enunciados de poder a partir deles que beneficiam o controle operado pelo Estado no alardeamento da ideia de um "Estado de Segurança" e nas práticas de controle judicial e social.

O percurso teórico traçado buscou passar pelas diversas fases da filosofia de Michel Foucault, explorando desde o contorno arqueológico até os trabalhos da biopolítica. Nessa ordem, o problema que pretendo abordar no presente trabalho versa acerca da observação do processo de formação dos "enunciados de poder" a partir das narrativas do jornalismo policial e com isso a verificação sobre a produção dos "infames" no espectro criminal.

Ponha-se em realce que as práticas discursivas, em especial no âmbito do jornalismo policial, desvelam uma tensão entre o sujeito sobre o

\footnotetext{
2Krasmann, Susanne. Von der Disziplin zur Sicherheit. Foucault und die Kriminologie. Foucaults Machtanalytik und Soziale Arbeit. Roland Anhorn, Frank Bettinger, Johannes Stehr (Hrsg.), Wiesbaden: VS Verlag, 2007. p. 155.
} 
Revista da Faculdade Mineira de Direito | v.21 N.41 78

qual se noticia (no âmbito do que as investigações alemãs denominam de übersubjektiven) e o potencial repressivo das agências de controle penal, "isso se deve ao fato de que o controle social nas sociedades pós-modernas é praticado em grande parte discursivamente, nomeadamente através das comunicações e das práticas simbólicas" 34 .

A produção dos enunciados reflete um aspecto relevante na circularidade dos poderes, sendo um campo vasto de observação do contemporâneo, pois a ampliação da inserção da mídia e o aparato das redes sociais favorece ao dinamismo de formação e deformação dos enunciados.

Por sua vez, o dispositivo jurídico que funciona a partir da transmissão de enunciados legais, é igualmente atingido pelos enunciados veiculados na rede e mídia, tais funcionalidades quando postas no ambiente criminal podem ser responsáveis pela construção de um padrão de estigmas e modelos de verdades com aptidão de fazer circular uma máquina de condenações no rastro da "pós verdade".

Desse modo, a pretensão foi fornecer respostas aos seguintes pontos: é possível indicar que a veiculação das notícias nos jornais policiais opera em escala estratégica para formação de enunciados de poder e verdade produzindo "corpos infames"? E ainda, pode-se dizer que a produção dos enunciados de saber-poder a partir do jornalismo policial interfere na constituição dos dispositivos jurídicos criminais?

Em termos metodológicos o presente trabalho pertence ao gênero teórico, método dedutivo e objetivo descritivo. Para obtenção dos resultados pretendidos foi utilizada no primeiro momento a técnica de pesquisa bibliográfica para delinear os conceitos foucaultianos e realizar um cruzamento com os saberes de teorias e práticas do direito. Nesse sentido, as ferramentas de análise do problema sócio-jurídico seguiram estritamente os elementos contidos na filosofia foucaultiana, assim a formação dos "enunciados" e "dispositivos" são explicados à luz dos pressupostos da

\footnotetext{
3 "Bestimmend dafür war der Umstand, dass soziale Kontrolle in spätmodernen Gesellschaften weitgehend diskursiv, also über Kommunikation und symbolische Praktiken, ausgeübt wird".

${ }^{4}$ KUNZ, Karl-Ludwig. Zur Symbolik des Strafrechts. Verbrechen, Strafe, Resozialisierung. Festschrift für Heinz Schöch zum 70. Geburtstag. Dieter Dölling, Bert Götting, Bernd-Dieter Meier, Torsten Verrel (Hgrs.). Berlin: de Gruyter, 2010. p. 3.
} 
Revista da Faculdade Mineira de Direito $\mid$ v.21 N.41 79

arqueologia e genealogia de Michel Foucault, nos termos da lógica dedutiva. A abordagem escolhida foi qualitativa com utilização multi-método, pois os conceitos teóricos foram trabalhados a partir das técnicas de observação, descrição e análise foucaultiana do discurso contido nos programas policiais. Para ilustrar tais impressões foram vistos e selecionados uma série de programas exibidos em reprise nos canais da internet, a rigor foram assistidos aos programas "Bronca Pesada", "Brasil Urgente", "Cidade Alerta", TV Jornal/ SBT, BAND, TV Record. Os casos retratados possibilitaram entrever questões relevantes, que vão desde o tratamento diferenciado do par vítima - agressor em termos de violação dos direitos de personalidade até o controle de edição cuidadoso com a finalidade de caricaturar o delinquente, sendo possível observar um conjunto de elementos direcionados à produção das subjetividades infames.

\section{2 "O visível e o enunciável": notas sobre a arqueologia foucaultiana e os reflexos na pré-compreensão do criminoso}

O método arqueológico foi descrito por Foucault em 1969, no livro Arqueologia do Saber. O método teve como ponto de partida a história das ideias, a qual é atribuída à tarefa de penetrar nas disciplinas existentes ${ }^{5}$, tratálas e reinterpretá-las - é a disciplina dos começos e dos fins, da descrição das continuidades obscuras e dos retornos, da reconstituição dos desenvolvimentos na forma linear da história. A descrição arqueológica, por sua vez, abandona os postulados e procedimentos da história das ideias na tentativa de fazer uma história inteiramente diferente daquilo que os homens disseram. Procura estabelecer a constituição dos saberes privilegiando as interrelações discursivas e sua articulação com as instituições, na tentativa de responder a como os saberes apareciam e se transformavam. ${ }^{6}$

${ }^{5}$ FOUCAULT,Michel. Surveiller et punir. Gallimard, 1993.

${ }^{6}$ AZEVEDO, R.C.S.; RAMOS, F.R.S. Arqueologia e genealogia como opções metodológicas de pesquisa na enfermagem. Revista Bras Enferm, Brasília (DF) 2003 maio/jun;56(3):288-291. Disponível em:

$<$ http://www.scielo.br/pdf/reben/v56n3/a14v56n3.pdf>. 
Revista da Faculdade Mineira de Direito | v.21 N.41 80

Nas "histórias" de Foucault não se assiste ao desenvolvimento de uma razão progressista, mas à constituição de materialidades, discursos e relações de força que se interagem. (...) trata-se de uma filosofia de tensões.

$\mathrm{O}$ ser e o não ser, o mesmo e o outro, o finito e o infinito. A arqueologia não mostra processos dialéticos, assinala violências entre $\mathrm{O}$ discursivo e o não discursivo. Nessa defasagem entre ambos os âmbitos se produzem problematizações, das quais surgirão efeitos de verdade. ${ }^{8} \mathrm{~A}$ produção da verdade é descoberta nas práticas. Os objetos são produtos das práticas. Portanto não há coisas, não há objetos; melhor dito, existem coisas ou os objetos que as práticas produzem. (o dado é produzido a através das práticas) ${ }^{9}$. Aqui é um ponto de produção do enunciado, isso revela fortemente a diferença da noção meramente gramatical que se costuma apontar nos enunciados para o entendimento de Foucault, uma vez que o autor assinala o enunciado enquanto um produto de práticas, uma formação discursiva em "ato" e que finda por consolidar uma função de verdade. Para observar um formato descritivo a partir dos elementos que compõem a fase arqueológica de Foucault, passemos a observar em breves linhas o que representa cada signo dessa etapa:

1. Enunciado: Foucault busca descrever rigorosamente, ou seja, materialmente, os enunciados relacionados com as estratégias sociais e políticas, e não apenas linguísticas. Um enunciado é inicialmente descrito pelo lugar que ele ocupa no espaço social e na história. É, acrescenta Foucault, um acontecimento que nem a língua, nem o sentido podem esgotar inteiramente" 10 ;

2. Arquivo: não é sinônimo de tradição, não se trata do conjunto de textos conservados por uma civilização, mas do "jogo das regras que determinam em uma cultura o aparecimento e o desaparecimento dos enunciados, sua

${ }^{7}$ DÍAZ, Esther. A filosofia de Michel Foucault. 1ª Ed. São Paulo: Editora Unesp, 2012. p. 12.

${ }^{8}$ DÍAZ, Esther. A filosofia de Michel Foucault. $1^{a}$ Ed. São Paulo: Editora Unesp, 2012. p. 12.

${ }^{9}$ DÍAZ, Esther. A filosofia de Michel Foucault. 1ª Ed. São Paulo: Editora Unesp, 2012. p. 13.

${ }^{10}$ FOUCAULT, Michel. A arqueologia do saber. Tradução de Luiz Felipe Baeta Neves. Revisão de Lígia Vassalo. Petrópolis: Vozes, 1972. p. 13. 
Revista da Faculdade Mineira de Direito | v.21 N.41 81

persistência e seu apagamento" "A arqueologia tem justamente por objeto recolher todas as marcas discursivas que permitam reconstituir essas regras. $^{12}$;

3. O discurso: as camadas discursivas, como classifica Foucault em As palavras e as Coisas, vai além da análise linguística. "O discurso corresponde a um conjunto de enunciados que têm as mesmas regras de funcionamento." ${ }^{\prime 13}$;

4. A episteme: designa as relações entre fenômenos e ciências e entre os tantos discursos científicos, é o alicerce sobre o qual se articulam os quadros gerais de determinada época. "todos os fenômenos de relações entre as ciências ou entres os diferentes discursos científicos" $" 14$.

Nessa esteira encontramos as verdades, as quais são produzidas a partir de técnicas, dos jogos de verdade, o que tornam legítimos e aceitos determinados discursos. Todos os conceitos foucaultianos expostos acima importam na organização das redes de saber-poder que contribuem na formação dos discursos e se fazem circular por meio deles.

A fase arqueológica do filósofo francês traduz essa preocupação com o "saber" e nessa trilha a importância da formação dos discursos, dos tipos de discurso e a relação da ordem discursiva nos campos de força, o que mais tarde será apresentado no espaço da disciplina e do controle. Nas obras como Arqueologia do Saber, História da Loucura, As palavras e as Coisas é possível adentrar nos processos de formação dos enunciados como zonas de representação política e como formas de subjetivação dos indivíduos. Foucault lança o desafio de percebermos como a ordem de discurso projeta um conteúdo de verdades e a partir daí temos uma précompreensão do objeto antes mesmo de conhecer esse objeto.

É neste ponto que se torna possível, ou ao menos razoável, pensarmos uma aproximação entre os processos de formação dos

${ }^{11}$ FOUCAULT, Michel. A arqueologia do saber. Tradução de Luiz Felipe Baeta Neves. Revisão de Lígia Vassalo. Petrópolis: Vozes, 1972. p. 22.

12 BERT, Jean-François. Pensar com Michel Foucault. São Paulo: Ed. Parábola, 2013. p.12.

${ }^{13}$ FOUCAULT, Michel. Vigiar e punir. $21^{\mathrm{a}}$ ed. Trad. de Raquel Ramalhete. São Paulo: Vozes, 2002b. p.29.

${ }^{14}$ FOUCAULT, Michel. Vigiar e punir. $21^{\mathrm{a}}$ ed. Trad. de Raquel Ramalhete. São Paulo: Vozes, 2002b. 
Revista da Faculdade Mineira de Direito | v.21 N.41 82

enunciados como mecanismos de interferência na subjetividade e como enunciados criminológicos derivados dessa estrutura de formação interferem no imaginário social em função da visibilidade do criminoso.

\section{$3 \mathrm{Da}$ formação discursiva do louco ao discurso do criminoso}

Na obra História da Loucura (1961), característica das preocupações da fase de investigação sobre o saber, Foucault indica desejar encontrar formas estruturadas de experiências, cujo esquema, possa ser encontrado, como modificação, em níveis diversos. No nascimento da clínica (1963) a partir da análise das clínicas médicas ele busca expor "a estrutura comum que divide e articula o que se vê daquilo que se diz", já em As palavras e as Coisas, ele busca um inconsciente do saber que, como inconsciente do indivíduo, merece observação com especificidade, isto porque para Foucault a história, o futuro e seus episódios “obedecem a certo número de leis e determinações" (2010). Essas obras constituem a tentativa de aplicar um método de estrutura no domínio dos conhecimentos, "O que tentei fazer foi introduzir análises de estilo estruturalista em campos em que elas até o presente não haviam penetrado, isto é, no campo da história das ideias, da história dos conhecimentos, da história da teoria. Nesse sentido fui levado a analisar em termos de estruturas o nascimento do próprio estruturalismo" 15 .

O estruturalismo permitiu atualizar uma série de redes anônimas de saber que fazem com que o homem não seja um ser inteiramente responsável por suas escolhas e criador dos próprios valores, mas um sujeito cuja ação esta associada ao seu tempo. A perspectiva "anti-humanista" que Foucault divide com Althusser, Pierre Bourdieu e Cláude Levi Strauss, apontando a impossibilidade de uma antropologia que teria como princípio fundador uma filosofia do sujeito livre e da história como liberdade ${ }^{16}$. Implica dizer que o mito de liberdade do sujeito é desafiado a partir da

15 FOUCAULT, Michel. Ditos \& escritos, vol. II. Rio de Janeiro, Forense Universitária, 2000b.

${ }^{16}$ BERT, Jean-François. Pensar com Michel Foucault. São Paulo: Ed. Parábola, 2013. p. 47. 
Revista da Faculdade Mineira de Direito | v.21 N.41 83

perspectiva de um sujeito que sofre a pressão do seu tempo e os limites reais dessa temporalidade.

E nesse sentido a composição desse sujeito vai sendo tecida através do visível e posteriormente daquilo que é dito. Para ilustrar o campo das visibilidades o filósofo percorre uma gama de imagens representativas na formação dos discursos de saber. Os chamados "bestiários morais" aparecem na História da loucura (1961), ou seja, descrições de animais reais ou imaginários que representavam simbolicamente os valores da humanidade, um desses animais fantásticos foi o Gutenmech $^{17}$, uma ave que se encontra em gravuras medievais. A principal característica do Gutenmech é um pescoço longo, o qual tinha a função de representar a elaboração do pensamento.

Este tem sua origem no coração e deve percorrer um longo trajeto até à cabeça. Quanto mais longo é o caminho, mais espirituais são os pensamentos; quanto mais lentamente sobem do coração à cabeça, mais tempo têm de ser equilibrados. A ave de pescoço muito longo simboliza um pensamento sutil e refinado. A sabedoria é representada com um pescoço em forma de alambique que indica uma reflexão elaborada, fina, paciente. Se o pensamento demora em ir do coração à cabeça, destila melhor suas impurezas. ${ }^{18}$

As alterações na imagem seguem até o desaparecimento do corpo da ave, resta somente a cabeça, a razão. Os silêncios das imagens apelam às ameaças da bestialidade e Foucault baseia-se naquilo que vê, no manifestamente visível, mas é esse visível que produz formações discursivas, pois a imagem processada é uma linguagem assimilada. Sem descuidar do dizível, também leva em consideração aquilo que é anunciado,

\footnotetext{
${ }^{17}$ Não existe palavra correlata em português, o Gutenmech era uma representação pictórica geralmente na figura de animais como dragões, leões ou seres híbridos.

${ }^{18}$ DÍAZ, Esther. A filosofia de Michel Foucault. 1ª Ed. São Paulo: Editora Unesp, 2012. p.16-17.
} 
nesse ponto o discurso humanístico aparece atravessado pela crítica moral dirigidas aos defeitos provenientes da loucura humana. A importância da História da Loucura (1961) está na ilustração da primeira utilização das categorias do visível e enunciável realizadas por Foucault e que serão tão caras à sua arqueologia ${ }^{19}$, as imagens da loucura e as enunciações sobre o louco atuam conjuntamente na formulação dos discursos.

As visibilidades e os discursos constituem quadros positivos indicadores de um marcador temporal que necessitam serem revelados. A época não preexiste aos enunciados que a expressam, nem às visibilidades que a ocupam ou como mais tarde expressa Butler que a linguagem nos precede $^{20}$. Toda formação histórica indica uma distribuição de discursividade e visibilidade por ela produzida. Deve-se procurar nos enunciados as visibilidades.

Os objetos ou coisas somente existem nas condições positivas de completo feixe de relações. Essas relações encontram-se esparsas entre as instituições, processos econômicos e sociais, formas de comportamento, sistema de normas, técnicas, tipos de classificação, modos de caracterização. ${ }^{21}$

A história da loucura ainda nos leva aos lugares de exclusão desde o fenômeno da lepra, a separação imposta aos leprosos (os quais experimentavam o castigo de Deus) até o surgimento da massa indiferenciada, que Foucault identificou como desrazão: os vagabundos, pobres, loucos, corruptos, libertinos, homossexuais, feiticeiros e prostitutas, todos eles ocuparam o espaço da exclusão social. Contudo deve ser registrado que a exclusão não é um fenômeno moderno, a Idade Média

${ }^{19}$ DÍAZ, Esther. A filosofia de Michel Foucault. 1ª Ed. São Paulo: Editora Unesp, 2012. p.18.

${ }^{20}$ BUTLER, Judith. Quadros de guerra: quando a vida é passível de luto. Rio de Janeiro: Civilização brasileira, 2015.

${ }^{21}$ DÍAZ, Esther. A filosofia de Michel Foucault. 1ª Ed. São Paulo: Editora Unesp, 2012. p. 22. 
Revista da Faculdade Mineira de Direito | v.21 N.41 85

utilizou as embarcações, os navios para excluir (limpar) as cidades dos loucos. O que a modernidade traz aos dispositivos de exclusão é o aperfeiçoamento.

$\mathrm{Na}$ História da Loucura (1961) Foucault entende que a forma mais óbvia de catalogar as formações discursivas seria o agrupamento dos atos discursivos que se referissem a um objeto comum. Contudo, na Arqueologia do Saber (1969) ele passa a compreender que as formações discursivas não são influenciadas pelos seus objetos, antes elas produzem o objeto sobre o qual falam.

A tendência de pensar a linguagem em termos de referente e de palavras que remetem aos objetos deve ser rejeitada. Ele afirma que "as palavras ficam tão deliberadamente ausentes quanto as próprias coisas". A arqueologia é, portanto, uma "tarefa que consiste não - não mais - em tratar os discursos como conjuntos de signos (de elementos significantes que remetem a conteúdos ou a representações) mas como práticas que formam sistematicamente os objetos sobre os quais falam". 22

Trata-se de um "espaço" onde diversos objetos se perfilam, tornamse visíveis e se transformam, tudo em relação de continuidade. Rabinow e Dreyfus apontam que a análise de Foucault parece concretizar as versões de Wittgenstein e Heidegger, visto que os três pensadores sustentam em suas teses que uma constelação de práticas permite àqueles que a utilizam diferenciar a falar dos objetos ${ }^{23}$. Ainda, "as relações discursivas estão de algum modo no limite do discurso: elas lhe oferecem os objetos dos quais ele pode falar (...), elas determinam o feixe de relações que o discurso deve

${ }^{22}$ DREYFUS, Hubert; RABINOW, Paul. Michel Foucault: uma trajetória filosófica. Rio de. Janeiro: Forense Universitária, 2013. p.82.

${ }^{23}$ DREYFUS, Hubert; RABINOW, Paul. Michel Foucault: uma trajetória filosófica. Rio de. Janeiro: Forense Universitária, 2013. p.82. 
Revista da Faculdade Mineira de Direito | v.21 N.41 86

efetuar para poder falar de tais e tais objetos, para poder trata-los, nomeálos, analisa-los, classifica-los, explica-los etc. ${ }^{24}$

Para explicar o papel de destaque ocupado pelas práticas discursivas Foucault compreende que sua existência não se dá por referencias objetivas ou subjetivas, mas sim pelo conteúdo relacional. Assim os cânones compartilhados nas práticas de discurso resultam da relação, do modo, da maneira como as relações primárias - descrição objetiva dada entre instituições, técnicas e formas sociais - e as relações secundárias - a definição dada pelos sujeitos das práticas para definir o próprio comportamento, como explicações sobre a criminalidade, a família se relacionam e são organizadas na prática discursiva.

Assim, a fonte dos discursos acontece a partir de um "campo anônimo" de práticas, o que segundo Rabinow e Dreyfus encontra ressonância e concordância dentre os pensadores hermeneutas como Heidegger e $\mathrm{Kuhn}^{25}$. A questão é tentar definir se existe uma regra geral na formação dos enunciados a partir desse espaço anônimo.

É possível, contudo, expressarmos uma ordem de formação de enunciado onde a mensagem não leva em conta somente o elemento objetivo ou subjetivo. É dizer que, em se tratando do campo da criminalidade, vale pensar no discurso e explicação concernente às instituições e função do Estado na grade segurança, nesse campo notemos que o discurso é fixado a partir de lei e norma, no nosso caso o próprio texto da CF/88 disporá sobre tais pontos e divisões de competência. Entretanto é preciso um grau de desdobramento desse papel institucional, aqui então podemos adentrar na enunciação subjetiva que levará em conta os sujeitos que compõe o ambiente institucional e suas "missões", outro espectro discursivo é formado, inclusive porque elementos de ordem moral, emocional e ética entram na elaboração do conteúdo subjetivo.

Pois bem, a partir dessa combinação do discurso objetivo institucional - objetivo por considerarmos apenas o texto normatizado - e o discurso subjetivo dos atores que compõem na esfera ativa as instituições

\footnotetext{
${ }^{24}$ Foucault. Em Defesa da Sociedade. São Paulo, Martins Fontes, 2002. p. 53;

DREYFUS, Hubert; RABINOW, Paul. Michel Foucault: uma trajetória filosófica. Rio de. Janeiro: Forense Universitária, 2013. p.83.

25 DREYFUS, Hubert; RABINOW, Paul. Michel Foucault: uma trajetória filosófica. Rio de. Janeiro: Forense Universitária, 2013. p.91.
} 
Revista da Faculdade Mineira de Direito | v.21 N.41 87

teremos a possibilidade de um campo discursivo do criminoso e do crime, essa formação discursiva vai obter características a partir de como são modulados os discursos nos planos objetivos e subjetivos, na medida histórica podemos observar que de tais relações vamos veicular um discurso do criminoso como um "anormal", como a curva de desvio da sociedade hígida. Por certo não podemos desconsiderar que esse sujeito criminoso também faz parte como um ator do campo subjetivo ${ }^{26}$, no entanto sua participação na formação da linguagem dar-se mais do ponto de vista estético e estratégico, ou seja, ele é apontado e de sua visibilidade deduz-se um discurso, mas ativamente sua participação é escassa, posto sua voz ter menor validade. Fato é que da equação Instituição e dever legal + Sujeitos institucionais e atuações "morais" e de segurança = definição do criminoso no campo social.

Vejamos um dos tons assumidos pela manutenção da ordem de prisão preventiva no direito nacional:

É recorrente a definição de risco para ordem pública como sinônimo de "clamor público", de crime que gera um abalo social, uma comoção na comunidade, que perturba a sua "tranquilidade". Alguns, fazendo uma confusão de conceitos ainda mais grosseira, invocam a "gravidade" ou "brutalidade" do delito como fundamento da prisão preventiva. Também há quem recorra à "credibilidade das instituições" como fundamento legitimante da segregação, no sentido de que se não houver a prisão, o sistema de administração de justiça perderá credibilidade. A prisão seria um antídoto para a omissão do Poder Judiciário, Polícia e Ministério Público. É prender para reafirmar a "crença" no aparelho estatal repressor.

\footnotetext{
26 PELLER, Mariela. Judith Butler y Ernesto Laclau. Reflexiones sobre la subjetividad, la historia y la política. XXVII Congreso de la Asociación Latinoamericana de Sociología. VIII Jornadas de Sociología de la Universidad de Buenos Aires. Asociación Latinoamericana de Sociología, Buenos Aires, 2009.
} 
Revista da Faculdade Mineira de Direito | v.21 N.41 88

No fundo, a garantia da ordem pública está em eterna crise de identidade. ${ }^{27}$

No mesmo sentido podemos notar os efeitos dessa discursividade e da formação dos enunciados no campo penal ao avaliar os resultados do "clamor público e social":

Como aponta Sanguiné, "quando se argumenta com razões de exemplaridade, de eficácia da prisão preventiva na luta contra a delinquência e para restabelecer o sentimento de confiança dos cidadãos no ordenamento jurídico, aplacar o clamor público criado pelo delito etc. que evidentemente nada tem a ver com os fins puramente cautelares e processuais que oficialmente se atribuem à instituição, na realidade, se introduzem elementos estranhos à natureza cautelar e processual que oficialmente se atribuem à instituição, questionáveis tanto desde o ponto de vista jurídicoconstitucional como da perspectiva políticocriminal. Isso revela que a prisão preventiva cumpre funções reais (preventivas gerais e especiais) de pena antecipada incompatíveis com sua natureza". ${ }^{28}$

No ambiente jurídico vale pensar como o objeto jurídico é determinado pela prática jurídica. A autorreferência do direito faz com que o próprio campo jurídico produza seu objeto, sua verdade, diga o direito. A força de lei, parafraseando Derrida, atinge o sujeito e a comunidade, mas parece ser menos orientado pelos sujeitos receptores da norma do que pelos intérpretes da norma, uma vez que são os juristas que dotam de conteúdo as leis e as situações de direito. Para se pensar uma estrutura de

${ }^{27}$ LOPES JR, Aury; ROSA, Alexandre Moraes da. Processo penal no limite. Empório do Direito, 2015.

${ }^{28}$ SANGUINÉ, Odone. A inconstitucionalidade do clamor público como fundamento da prisão preventiva. Revista de estudos criminais, n. 10. Porto Alegre: Nota dez. 2003. p.114. 
Revista da Faculdade Mineira de Direito | v.21 N.41 89

interpretação do direito nesse viés é preciso recusar padrões de racionalidade moderna tão impregnados na experiência jurídica e adotar um método com certo distanciamento da razão do "dever ser", serve-nos a lição de Foucault:

Para tal, como precaução metodológica, é preciso recusar todas as categorias que atribuímos de antemão aos textos e conjuntos de textos: noções como obra, autor, teorias, espíritos de época, disciplinas e divisões pré estabelecidas, como aquela entre senso comum e ciência são recusadas. A arqueologia busca assim instaurar-se num murmúrio sem nome, no anonimato do discurso que são os textos de um período e região, de preferência curto; fazer uma leitura imanente dos textos, sem prejulgá-los com categorias; as categorias serão encontradas nos próprios critérios de discernimento do momento histórico. ${ }^{29}$

A partir da definição de acontecimento como irrupção de uma singularidade histórica, Foucault vai desenvolver dois discursos. O primeiro consiste em dizer que nós repetimos sem o saber os acontecimentos, "nós os repetimos na nossa atualidade, e eu tento apreender qual é o acontecimento sob cujo signo nós nascemos, e qual é o acontecimento que continua ainda a nos atravessar" ${ }^{30}$. A acontecimentalização da história deve, portanto, se prolongar de maneira genealógica por uma acontecimentalização de nossa própria atualidade. O segundo discurso consiste precisamente em buscar na nossa atualidade os traços de uma "ruptura acontecimental" - traço que Foucault localiza já no texto kantiano consagrado às Luzes, e que ele crê reencontrar por ocasião da revolução iraniana, em 1979 - porque está aí, sem dúvida, o valor de ruptura de todas

${ }^{29}$ A filosofia analítica da política. In: Foucault. Ditos e Escritos V - Ética, sexualidade, política.Rio de Janeiro: Forense Universitária, 2004. p.123.

${ }^{30}$ A filosofia analítica da política. In: FOUCAULT, Michel. Ditos e Escritos V - Ética, sexualidade, política.Rio de Janeiro: Forense Universitária, 2004. p.145. 


\section{Revista da Faculdade Mineira de Direito | v.21 N.41 90}

as revoluções: "A revolução [... ] corre o risco de banalizar-se, mas como acontecimento cujo próprio conteúdo é importante, sua existência atesta uma virtualidade permanente e que não pode ser esquecida"'. ${ }^{31}$

Não se trata de uma tarefa fácil analisar as obras que compõem a arqueologia, entretanto parece fundamental entender parte da trajetória empregada por Foucault para atingir as noções contemporâneas dos discursos de governamentalidade, sujeições, biopoder e e demais conceitos que servem como caleidoscópio do presente. "Suponho que em toda sociedade a produção do discurso é a mesmo tempo controlada, selecionada,organizada e redistribuída por certo número de procedimentos que têm por função conjurar seus poderes e perigos, dominar seu acontecimento aleatório, esquivar sua pesada e temível materialidade"32.

Como descreve Didier Eribon ${ }^{33}$ acerca da relação de Foucault com sua arqueologia: "ele escreve com ardor e se debate como um demônio em meio a noções de enunciado, formação discursiva, regularidade e estratégia". Todo um vocabulário que tenta estabelecer e fixar; todo um jogo de conceitos que se esforça para definir e articular. E o próprio Foucault nos revela:

Explicar o que eu quis fazer nos livros onde tantas coisas ainda ficaram obscuras? Não só, não exatamente, mas indo um pouco além, retornar, como em outra volta da espiral, aquém do que empreendi; mostrar de onde eu falava; delimitar o espaço que possibilita essas pesquisas e outras, talvez, que nunca realizarei; em suma, dar significado a essa palavra arqueologia que eu tinha deixado vazia. ... e onde a história das idéias, decifrando os textos, procura revelar os movimentos secretos de pensamento (sua lenta

${ }^{31}$ REVEL, Judith. Michel Foucault - conceitos essenciais. São Carlos: Claraluz, 2005. p. 15.

${ }^{32}$ FOUCAULT, Michel. História da sexualidade, vol.1, A vontade de Saber. Rio de Janeiro: Graal, $17^{a}$ edição, 2006. p.9.

${ }_{33}$ ERIBON, Didier. Michel Foucault - uma biografia. Trad. de Hildegard Feist. São Paulo: Companhia das Letras, 1990. p.178. 
Revista da Faculdade Mineira de Direito | v.21 N.41 91

progressão, suas lutas e recaídas, os obstáculos contornados), eu queria evidenciar em sua especificidade o nível das "coisas ditas": as condições de seu surgimento, as formas de sua cumulação e de seu encadeamento, as regras de suas transformações, as descontinuidades que as escandam. O terreno das coisas dita é o que se chama Arquivo; a arqueologia destina-se a analisalo. ${ }^{34}$

Nesse sentido, é posta a questão sobre a possibilidade de avaliar as categorias discursivas dentro do Arquivo do campo criminal e se estas categorias discursivas são responsáveis por alguns efeitos contemporâneos que subjazem aos sujeitos criminosos. Um grande jogo de imagens e falas é sempre projetado em torno da questão criminal, as narrativas dos crimes, a publicização da imagem dos criminosos, os cuidados com segurança pressupondo, via de regra, modelos de padrão de criminalidade e as estatísticas atualizadas em tempo real são elementos que parecem contribuir na construção de uma identidade visual e social do criminoso. A junção desses elementos em ordem repetitiva favorece a formação de enunciados criminológicos, observando a justaposição do visível e do enunciável.

\section{Uma arqueologia criminológica: as narrativas policiais e a construção dos enunciados de saber criminal}

Em tempos contemporâneos não podemos ignorar a participação ativa dos espaços midiáticos na formação e composição dos enunciados. Conforme exposto, aquilo que confere valor de enunciado não é tão somente o que se enuncia, mas toda a trama de informações, repetições e estética nos atos de linguagem. Nesse sentido, podemos destacar um forte efeito das circulações de notícias seja na mídia escrita, digital ou televisiva naquilo que diz respeito ao campo do crime.

${ }^{34}$ FOUCAULT, Michel. A arqueologia do saber. Tradução de Luiz Felipe Baeta Neves. Revisão de Lígia Vassalo. Petrópolis: Vozes, 1972. p.178. 
Revista da Faculdade Mineira de Direito | v.21 N.41 92

O título do presente tópico faz alusão a um dos programas de jornalismo policial exibidos na TV aberta e disponível no ambiente virtual, com isso pretende-se chamar atenção para o nível de linguagem empregada e a contribuição para a formação de enunciados acerca dos perfis criminosos, da alta incidência do crime e do grave painel de insegurança que supostamente parece ser a regra no cenário nacional e local. Destacamos a sistemática de formação de enunciado de violência, qual seja:

1. Transmite-se um flagrante conduzido por uma equipe policial do interior de uma delegacia;

2. O repórter e o apresentador emitem juízos valorativos, ora de forma direta, ora de forma reflexa;

3. O telespectador capta a informação filtrada pelo profissional da mídia e não qualquer potencial reflexão;

4. Em conjunto com a linguagem falada, explora-se a linguagem gestual e a exposição do "criminoso" e, raramente, da vítima;

5. O criminoso ou criminosa é costumeiramente retratado de forma cômica, "noiada" ou animalesca;

6. O delinquente é "espetacularizado" sendo exposto, não só em sua imagem, mas em ofertar respostas ao repórter, tudo sem qualquer grau de cuidado ou respeito a direitos de personalidade;

7. O perfil dos delinquentes apresentados nestes programas costuma se alinhar com indicadores de raça e condição sócio econômica localizados em setores marginais do conjunto social;

8. Como resultado tem-se, não raro, o seguinte enunciado: a violência é absolutamente banal e cotidiana, sendo premente o estado de insegurança; os criminosos possuem perfil em grande parte assemelhados aos setores da comunidade negra e com menor instrução educacional, painel que retroalimenta um sistema de preconceitos estruturantes.

Os consumidores das notícias não costumam refletir acerca dos fatos descritos, na mesma linha os profissionais da mídia não possuem como escopo problematizar os sinais de violência ou o sistema criminal, há uma intenção de construir um produto de fácil venalidade para a população e que capte a atenção de maior número de telespectadores. Tudo realizado 
Revista da Faculdade Mineira de Direito | v.21 N.41 93

dentro de uma circularidade estética e de linguagem, mas com um comprometimento "capital".

Há uma certa perversidade na formação dos enunciados que acompanham o campo criminal, pois todos trabalham no campo dos afetos, posto que a forma como se aborda a questão do crime pode desembocar na sensação do medo, revolta, insegurança ou raiva, componentes que extrapolam o círculo da dogmática penal e igualmente do sensacionalismo midiático. Notadamente, percebe-se a invasão nos campos das subjetividades, desde o criminoso, o qual é retratado de modo a ter ignorada sua subjetividade ${ }^{35}$ e da população que é seduzida pela notícia e projeta suas emoções a partir do dado, contribuindo assim para a produção do enunciado de verdade.

Para ilustrar tais impressões foram vistos uma série de programas exibidos em reprise nos canais da internet, a rigor foram assistidos aos programas "Bronca Pesada", "Brasil Urgente", "Cidade Alerta", TV Jornal/ SBT, BAND, TV Record respectivamente, o primeiro jornal local apresentado pelo conhecido "Cardinot", o segundo apresentado pelo famoso "Datena" e o terceiro pelo jornalista Marcelo Rezende. A maratona de programas policiais teve duração de cinco dias, tendo em média entre 15 e 20 horas líquidas de notícias, deu-se preferência a matérias de 2011 ao corrente ano de 2017, optando-se por uma mescla de exemplares de 2011, 2014,2016 e 2017 . Os casos retratados trazem algumas questões intrigantes, inclusive no tratamento diverso quanto ao direito à imagem conferido ao suposto criminoso e à vítima, assim como a forma jocosa ou monstruosa que os profissionais desde o apresentador, repórter até o controle de edição do programa tentam imprimir no que diz respeito ao delinquente.

Outrossim, parece-nos que não há muita diferença na edição da notícia policial de 2011 até 2017, implica dizer que ainda no que diz respeito ao alardeado discurso atual de maior índice de violência e carência de segurança, naquilo que tangencia ao modo de exibição das notícias, tanto os anos anteriores como agora imprimem o mesmo caráter assombroso e de alta performance espetacular. Passamos, de modo muito breve, a descrever alguns quadros:

${ }^{35}$ FOUCAULT, Michel. Dits et écrits 2 (1976-1988). Coleção Quarto, Gallimard, 1995, p. 73. 
Revista da Faculdade Mineira de Direito $\mid$ v.21 N.41 94

1. "Soninho"- programa exibido em junho do corrente ano onde o repórter introduz a matéria dizendo que flanelinha assaltou e levou a mochila de estudante de engenharia no recife antigo e depois de preso aproveitou para tirar um "soninho" na delegacia. Em seguida ele conta que o estudante estava tirando fotos para a formatura e decidiu colocar o carro numa rua mais movimentada por segurança e mesmo assim não adiantou; depois corta a fala para dizer que interrompeu o "soninho" do bandido para perguntar e o flanelinha negou ter feito o roubo; logo em seguida aparece uma mulher com um tampão em um dos olhos, garota de programa da região, e o repórter diz que o verdadeiro motivo do crime foi revelado, no que a mulher diz, de forma embaraçada e apressada, que o flanelinha chamou pra o assalto porque queria fazer um programa, o repórter (que não aparece) pergunta se a faca era dela (e a câmera centraliza a faca) e a mulher responde que sim, que a faca é dela! Como arremate da matéria o repórter fala com a vítima sobre sua perda, aqui é interessante notar que a vítima tem a imagem preservada pela técnica de desfocar a imagem e a voz alterada para não haver reconhecimento, o rapaz então conta que recuperou bolsa e computador, mas perdeu dois meses de documentos de trabalho e agora vai ter quer recuperar, o fundo da gravação sugere algo dramático.

2. Moças na Av. Caxangá tentam assaltar evangélica - A exibição da matéria inicia narrando que duas mulheres assaltaram evangélica que estava voltando da igreja, durante a narrativa já se apresenta o interior da delegacia com duas mulheres visivelmente alteradas (a atitude sugere o consumo de drogas) uma negra e com tranças estilo rastafári e outra branca de olhos verdes com cabelos descoloridos (provavelmente por água oxigenada); a negra mexe as tranças e sorri desesperadamente dizendo que "não pegou nada não" e a branca diz que "não precisa pegar nada de ninguém, que ganha o dela com os programa", a negra não para de sorrir de forma descontrolada e virar de um lado para o outro. O repórter (que não aparece) pergunta a vítima o que aconteceu, a mulher conta que estava saindo da igreja com um grupo e as pessoas pegaram o ônibus e ela ficou, nisso ela viu as duas mulheres que apontavam para ela e logo em seguida as mulheres agarraram a sua bolsa (câmera filma a bolsa em imagem centralizada), conta então que um carro ia passando com um casal e pararam para salvá-la, fala de Deus. A edição do programa corta então para as duas mulheres e o repórter pergunta 
Revista da Faculdade Mineira de Direito | v.21 N.41 95

se a branca faz programa, de uma forma desconectada a mulher responde que faz e fala que tem marido, que não precisa de roubo não, o repórter pergunta se o marido sabe que ela faz programa ao que ela responde "lógico!" e "num vou dizer não?!", o repórter então pergunta se ela divide o dinheiro do programa com ele (note-se que a pergunta não tem relevância com o flagrante) a mulher então responde "e eu vou dividir com quem? Com tu é?", enquanto isso a negra continua com gestos descontrolados, a edição então joga palavra "loka" na tela e o som de uma música que repete "loka,loka,loka" enquanto as palavras aparecem no vídeo.

3. O melhor do "Bronca pesada" com Cardinot - O apresentador começa o programa logo disparando um feixe de notícias policiais em tom firme e quase sem espaçamento entre as falas: assalto em estação de metro; tiroteio em areias; bronca do tamanho do trem; ( grifo nosso) menor de 16 anos morre com 7 tiros, dois feridos com balas perdidas; adolescente de 17 anos alvejada com 5 tiros. Em seguida corta para noticiar banho de moradora de rua em Brasília; música "banho de cheiro" e um ar humorístico substitui o tom policial; logo em seguida, novo fôlego e novas notícias policiais: fuga de prisão; venda de crack em bar, nessa parte a edição mostra o "elemento" preso com a droga e o dono do bar, o repórter então vai entrevistar o acusado que de forma desconectada e pouco audível nega o crime, por sua vez o dono do bar, jovem de 25 anos, diz que só era dono do bar e não era obrigado a saber dessas vendas no bar não, que não tem nada a ver com isso, só vende bebida; nesse mometo volta para Cardinot e o apresentador começa "o problema é que isso aqui é Brasil, aí ô dono do bar, se isso aqui fosse EUA era cadeia, e não era por droga não, era por vender bebida a menor". O apresentador continua expressando seu juízo de valor e pergunta se voltando ao telespectador: "e a menor não tem pai não, aí tá com a droga e quando a polícia chega coloca a droga dentro das partes íntimas" (...) corrupção de menores colocava pra 20 anos, hediondo, hediondo, hediondo, é a impunidade pra menor, quem vender se descobrir, arromba o cara... mas ninguém mete a mão nas lei do brasil, só mete pra soltar e já começou ser solto bandido aqui em PE, hein? É bom lembrar"e sem grande conclusão passa a outra narrativa e comercial de produtos parceiros. ${ }^{36}$

\footnotetext{
${ }^{36}$ Registro que os trechos narrados estão expostos em um canal do youtube destinado ao programa e segundo informações coletadas no espaço virtual correspondem a reprises de
} 
Revista da Faculdade Mineira de Direito | v.21 N.41|96

4. Ainda Cardinot - Em setembro de 2016 o apresentador estreia um novo programa na TV jornal chamado "por dentro com Cardinot", o formato do programa oferece plataformas mais plurais, mas ainda com quadros de jornalismo policial e traz elemento de interação com o público através de enquetes. Em um dos programas assistidos a enquete pergunta: Você tem medo de andar de ônibus no Grande Recife? A pergunta da enquete é precedida de um breve cenário de assaltos nas linhas de ônibus e trajeto feito em suposta linha mais perigosa da cidade do Recife, ao longo do programa algumas chamadas sobre o tema e a chamada para a própria enquete. No final com tom de extrema gravidade e pausado o apresentador anuncia que $97,84 \%$ da população tem medo de andar de ônibus!

5. O tinhoso - No Cidade Alerta o apresentador inicia a chamada falando que vai aparecer agora "um tinhoso" que tem 8 assassinatos, agressivo, violento e então corta para o repórter, este vai pra cima do acusado que está algemado e preso a uma moto em uma garagem com outros veículos, e indaga repetidamente "o que foi que cê fez?" tá sendo acusado de matar um cidadão! Enquanto fala manobra o microfone na frente do suspeito, o acusado então tenta chutar o repórter, mas tem os movimentos limitados pelo peso da moto a qual está algemado; balbucia algumas frases de raiva e com dicção pouco clara; o repórter anuncia então: "olha o grau de periculosidade desse marginal, desse bandido, querendo agredir nossa equipe" e diz que parece que o acusado mentiu sobre o nome e pergunta: "teu nome é Miguel mesmo"? Tudo isso ocorre em público e com curiosos acompanhando pela calçada. Interessante toda a construção da cena e a narrativa exibida pelo programa, pois sem que haja a ficha de antecedentes de fato e informação sobre culpabilidade, transito em julgado, o repórter e o apresentador criam uma "caricatura do monstro" para o acusado e transmitem como enunciados verdadeiros. Em nenhum momento a brecha para se pensar o criminoso como também humano ${ }^{37} \mathrm{e}$

julho de 2011 atendendo a pedidos dos telespectadores. O número de acessos até a data que assisti ao programa ultrapassava meio milhão de visualizações.

${ }^{37}$ FOUCAULT, Michel. Le corps utopique, Les heterotopies. Lignes, 2009, p.33. 
Revista da Faculdade Mineira de Direito | v.21 N.41 97

passível de emoções como vergonha, humilhação, raiva ou simples desejo de privacidade parece surgir na edição do programa ${ }^{38}$.

A linguagem empregada pela mídia, a comunicação em voga constitui um certo tipo de prática discursiva, nesse cenário há muita sintonia com a atenção que Michel Foucault dedicou ao enunciados e práticas discursivas. Sim, práticas no plural, pois não há um único fio de discurso, mas um emaranhado de práticas discursivas que fazem circular feixes de poder, de micropoderes que penetram as capilaridades subjetivas e sociais.

Nessa senda, a prática discursiva que ecoa a partir da malha de comunicação policial reflete, por assim, dizer nos dispositivos de poder que compõe o campo criminal, vez que a força circular de tais enunciados alcança não somente aquilo identificado como opinião pública, mas igualmente fornece material às razões de governo e aos dispositivos jurídicos que tanto se expressam em comando decisórios de sentenças como na atuação das demais funções de amparo e captação dos setores criminais, como Ministério Público, Política das Polícias e Legislativo. Um fenômeno que pode ser, por analogia, sintetizado em uma das observações aguçadas encontradas na doutrina de Cláudio Brandão quando trata a crise em torno da questão penal e da tipicidade "Esta crise é o produto da alienação técnica do político com a alienação técnica-política do técnico" ${ }^{\text {”3 }}$. Em síntese, o jogo perigoso em questão implica na influência dos enunciados midiáticos diante da classe legislativa - mens legislatoris - e a confecção de leis penais atécnicas, carentes de fundamentação científica e com propósitos imediatistas, o que deslegitima a própria doutrina penal.

Convém, igual modo, avaliar os efeitos que os discursos midiáticos promovem ao estabelecerem padrões de análise dos autores dos crimes, nesse ponto é imporante divisar a preocupação do jornalismo policial em identificar a figura do criminoso e o seu suposto modo de ação em detrimento de qualquer preocupação com o escopo técnico do crime. Por sua vez, a reprodução de um discurso criminal que parte do criminoso e

\footnotetext{
38 Todos os links de acesso para os programas estão ordenados nas páginas de referências utilizadas no presente trabalho.

${ }^{39}$ BRANDÃO, Cláudio. Tipicidade penal: dos elementos da dogmática ao giro conceitual do método entimemático. Coimbra: Almedina, 2012. p.24.
} 
Revista da Faculdade Mineira de Direito | V.21 N.41 $\mid 98$

ignora desde o entorno social até a crítica dogmática do crime, o que se tem é o debate criminal a partir do autor e um conjunto de esforços voltados para a produção de um criminoso perverso, não recuperável, um corpo infame, digno somente de violência. Novamente é possível indicar as relações entre a visibilidade criminal trabalhada a partir da mídia e a produção caótica do discurso legiferante de mais punição, não raras vezes justificado pela suposta incorrigibilidade do criminoso, nas palavras de Zaffaroni "a racionalização dos tipos de autor é o sinal mais crasso de desorientação metodológica do direito penal, que inverte sua função e põese a serviço do estado policial" ${ }^{40}$, mais uma vez entra em cena a dita "alienação técnica dos políticos" $"$. Alguns episódios que originaram alterações na legislação penal servem como quadro exemplificativo da utilização do discurso midiático espetacularizante como razão do endurecimento das penas, para tanto a lei de crimes hediondos, o acréscismo do parágrafo $5^{\circ}$ ao artigo 155 do $\mathrm{CPB}$, prevendo aumento da pena no caso de furto de veículos e envio para outro espaço territorial, ou ainda o debate atual de redução da maioridade penal, todos são casos onde o debate jurídico-penal foi esvaziado e substituído pelo debate massificado veiculado em jornais e afins.

Deve-se levar em conta também a natureza dessa atuação dos profissionais de mídia, o que os jornais policiais ou as notícias referentes aos crimes visam como finalidade é algo desvinculado do trabalho técnico jurídico. Esse conjunto profissional atuante pertence a outra categoria de trabalho, o que de per si carrega uma marca do contemporâneo, um trabalho que faz a partir de uma prática imaterial. Talvez não seja demais lembrar que esse trabalho imaterial opera em um duplo aspecto, se por um lado traz um viés de liberdade ao próprio trabalho, por outro ado é também formatado por uma relação de forças que não se deixam esquecer o propósito do consumo.

40 ZAFFARONI, Eugenio Raúl ET al. Direito penal brasileiro: teoria do delito, introdução histórica e metodológica, ação e tipicidade. Rio de Janeiro: Revan, 2010. ${ }^{41}$ ZAFFARONI, Eugenio Raúl. En torno de la cuestión penal. Buenos Aires: Editorial B de F, 2005. 
Revista da Faculdade Mineira de Direito $\mid$ v.21 N.41 99

$\mathrm{O}$ que caracteriza o trabalho imaterial, tendencialmente predominante no capitalismo de hoje, é que por um lado para ser produzido ele exige sobretudo a subjetividade de quem o produz, no limite até os sonhos e crises são postos a trabalhar, e por outro que os fluxos que ele produz, de informações, de imagem, de serviços, afetam e formatam sobretudo a subjetividade de que os consome. Nunca a obsessão de Guattari de que a subjetividade está no coração da produção capitalística fez mais sentido do que hoje. ${ }^{42}$

Ainda no rastro da interpretação biopolítica de Pelbart "Não só a subjetividade está nas duas pontas do processo, da produção e do consumo, mas a própria subjetividade tornou-se "o" capital" "43. Desafiadora a afirmação, mas plausível em absoluto, nesse pequeno recorte de jornalismo policial é flagrante a construção da notícia não somente a partir da informação, mas também com a carga emocional, estética daquele que informa; na mesma via, não se pode negar a intenção de selecionar determinado alvo enquanto público e essa seleção opera a partir da subjetividade, logo a "minha subjetividade" é produto e a "subjetividade que alcanço” também é produto.

infames

$5 \mathrm{Da}$ força do enunciado ao controle biopolítico dos corpos

A intenção demonstrada até o presente momento revelou-se na indicação da formação daquilo que Foucault tratou como "enunciados" na fase arqueológica. De modo preciso, tento demonstrar a formação de enunciados criminológicos derivados da estética do jornalismo policial e enquanto "enunciado" temos a formação de um discurso resultante dos

42 PELBART, Peter Pál. Vida Capital: ensaios de biopolítica. São Paulo : Iluminuras, 2009. p. 147.

43 PELBART, Peter Pál. Vida Capital: ensaios de biopolítica. São Paulo : Iluminuras, 2009. p. 147. 
usos de imagens e falas em uma ordem de repetição que findam por fixarem conteúdos de verdade com poder massificante. Contudo, a produção dos corpos infames na ordem dos enunciados criminológicos derivados da lógica do jornalismo policial implicam uma outra linha de observação também apresentada pelo filósofo francês, com isso quero dizer que a produção dos infames serve à lógica expressa nos padrões de biopoder e técnicas de controle biopolítico de gerenciamento da vida.

Foucault forjou a noção de biopoder para mapear um regime que tomava por objeto a vida. O centro gravitacional da noção de biopoder é traduzido em um potencial repressivo ${ }^{44}$, já que a vida já não era mais aquilo que o poder reprimia, mas aquilo que ele se encarregava, que ele geria e administrava, o biopoder se interessava pelas condições de produção e reprodução da população enquanto espécie, enquanto vida. O estudo do biopoder dá-se declaradamente por meio da criação do dispositivo de segurança, diferente tanto da soberania como da disciplina, invertendo-a: é o direito de fazer viver e deixar morrer. É porque o soberano pode matar que ele exerce seu direito sobre a vida. É essencialmente um direito de espada. (...) Não é o direito de fazer morrer ou fazer viver. Não é tampouco o direito de deixar viver e de deixar morrer. É o direito de fazer morrer e deixar viver. ${ }^{45}$

As teias biopolíticas são bem traçadas e vão desde a formação do enunciado, passando pela prática discursiva até um controle de vida, melhor dizendo: vidas. Os meios midiáticos de alcance criminológico veiculam fluxos imateriais de formas de vida e nos fazem consumir formas de vida. Trata-se de uma nova roupagem do capital, um avanço biopolítico onde nada lhe escapa, como escreve Pelbart "o capital penetra a vida numa escala nunca vista e a vampiriza." ${ }^{46}$.

Do enunciado ao corpo infame existe uma passagem, um controle que vai atravessar a ordem da linguagem e atingir o corpo, atravessando-o

${ }^{44}$ É o que desvela explicitamente Ulrich Kobbé, verbis: "Bleibt anzumerken,dass jeder `Biomacht< eine »repressive Möglichkeit« innewohnt." (Deve-se notar Todo "biopoder" tem um "potencial repressivo"). KOBBÉ, 2010, P. 18

${ }^{45}$ FOUCAULT, Michel. Em Defesa da Sociedade. São Paulo, Martins Fontes, 2002. p. 287.

46 PELBART, Peter Pál. Vida Capital: ensaios de biopolítica. São Paulo : Iluminuras, 2009. p. 149. 
igualmente. Em termos biopolíticos o que temos é a valoração, indicação e resolução sobre a vida de um conjunto determinado de sujeitos. $\mathrm{O}$ visível e o dizível como formas abstratas na formação de um discurso de poder punitivo e os corpos infames como objetos materiais de controle e investimento biopolítico cuja finalidade é a exclusão. O conteudo tem uma forma e uma substância: a prisão por exemplo, e os que nela estão encerrados, os presos (quem? Por quê? Como?). A expressão também tem uma forma e uma substância: o direito penal, por exemplo, e a delinquencia enquanto objeto de enunciados ${ }^{47}$. A razão dessa análise das formações discursivas de poder punitivo de caráter filosófico, sociológico e político importarem ao sistema de direito penal consiste no reconhecimento da dogmática penal como limite entre a fala, a escrita e o corpo do condenado.Dentro do direito, o direito penal representa o limiar dessa sensibilidade. $^{48}$

Penso ainda na maneira como um conjunto tão prescritivo quanto o sistema penal procurou seus suportes ou sua justificação, primeiro, é certo, em uma teoria do direito, depois, a partir do século XIX, em um saber sociológico, psicológico, médico, psiquiátrico: como se a própria palavra da lei não pudesse mais ser autorizada, em nossa sociedade, senão por um discurso de verdade. ${ }^{49}$

Voltando ao enunciado e a funcionalidade da mídia, é preciso cuidado extremado no jogo valorativo da mídia contemporânea, certo que não há como retirá-la dos holofotes, posto que sua influência atinge todas as esferas sociais e no campo jurídico muitos efeitos são observados a partir dos produtos midiáticos. De toda sorte, alguns autores convidam a pensar em outras vertentes: "sejamos claros: a sociedade do consumo mais libera

${ }^{47}$ DELEUZE, Gilles. Foucault. 6a ed. São Paulo: Brasiliense, 2006. p. 56.

48 GIORGIO, Raffaele De. Direito penal e teoria da ação entre hermenêutica e funcionalismo. Veredas do direito, v.3, jul/dez 2004, Belo Horizonte:Escola Superior Dom Helder, 2004. p.11.

${ }^{49}$ FOUCAULT, Michel. História da sexualidade, vol.1, A vontade de Saber. Rio de Janeiro: Graal, $17^{a}$ edição, 2006. p.19. 
Revista da Faculdade Mineira de Direito | v.21 N.41 102

do que oprime. A obsessão pelo "ter", obviamente, domina mais os pobres do que os ricos, pois vem da necessidade. (...) a publicidade não consegue fazer com que se deseje o indesejável"50.

Ainda que ousado expor que a notícia policial e os enunciados de ordem criminal constituem também um feixe de "desejos" e igualmente são pensados como produtos de consumo, parece abrir-se um razoável campo de abordagem nessa reflexão. Conforme orientado antes, trata-se de um evento biopolítico, das subjetividades atuantes até as subjetividades tomadas como alvo.

No aspecto midiático do jornalismo policial a forma como a violência é tratada tem um papel importante ao construir um espaço e uma forma de vida de "terror" para o qual pode ou deve ser dirigida a raiva gerada socialmente. Vale dizer que a violência é apresentada como marca de determinados sujeitos, de determinadas formas de vida, como explica Davi Romão em entrevista concedida ao canal da USP: “O jornalismo Policial apresenta os 'criminosos' e 'vagabundos' como a fonte de todos os problemas que nos atingem. A estrutura do programa precisa direcionar para longe de si a raiva que ela mesma gera e o criminoso recebe em si tudo o que nossa ordem social nos obriga a reprimir". ${ }^{51}$

O mesmo autor aponta como resultado na sua pesquisa de dissertação de mestrado o seguinte: "Como esses criminosos são, em sua maioria, jovens do sexo masculino, pobres e pardos, os preconceitos do Jornalismo Policial misturam-se com preconceitos de classe historicamente presentes em nossa sociedade"

O jogo de cena tem papel fundamental na circulação da notícia policial, a estética, o gestual, tudo acompanha o enunciado posto em prática discursiva. O papel de autoridade, falando assertivamente, elevando o volume da voz, induzindo o público a concordar, os apresentadores

${ }^{50}$ LIPOVETSKY, Gilles. Sedução, publicidade e pós-modernidade. In: LOPES,Jr; limite penal e crise de identidade e ordem pública: fundamento para prisão preventiva. Disponível em: < http://www.conjur.com.br/2015-fev-06 >. p.33/34.

${ }^{51}$ Matéria publicada no portal de notícias da USP - Psicologia em 08.04.2013.

52 ROMÃO, Davi Mamblona Marques. "Jornalismo Policial: indústria cultural e violência”. Dissertação de Mestrado apresentada no Programa de Pós Graduação em Psicologia da USP, 2013.Disponível:

$<$ www.teses.usp.br/teses/disponiveis/47/47131/tde-30072013.../romao_corrigida.pdf>. 
Revista da Faculdade Mineira de Direito | V.21 N.41 | 103

constroem um cenário no qual ocupam a posição de referência moral. Como aponta o pesquisador da USP:

Apresentam uma visão de mundo cristalizada, que não permite qualquer tipo de questionamento ou tensão. É como se a verdade sobre o mundo fosse entregue em domicílio através da televisão. Nesse sentido, temos como saldo pessoas com uma subjetividade completamente dependente, incapaz de ver a si mesmas participando ativamente dos processos políticos que as afetam ${ }^{53}$

É inegável o aspecto de instrumentalização biopolítica na linha de organização do jornalismo policial, se corpos e subjetividades são atacadas na formação da notícia, mesmo lado são os corpos e as subjetividades de determinados segmentos da sociedade que constituem o público alvo desse produto da mídia. Nesse ponto, cabe atentar que "a informação é qualificada em função se sua capacidade de gerar proxemia" ${ }^{54}$. Percebemos como o ambiente da subjetividade é constituído enquanto elemento no cenário da comunicação, isto observado a partir das teses dos próprios comunicólogos. Vejamos, tratar a proxemia é criar um padrão de eficiência no controle das distâncias, é traçar uma rota de onde, como e a quem aproximar ou encurtar os espaços.

Ainda com Maffesoli, "comunicação e informação descrevem um modus vivendi característico da pós-modernidade" ${ }^{55}$. Não há uma rede que escape ao consumo de informação cotidiano, parece-nos que o "arquivo"

\footnotetext{
${ }^{53}$ ROMÃO, Davi Mamblona Marques. "Jornalismo Policial: indústria cultural e violência”. Dissertação de Mestrado apresentada no Programa de Pós Graduação em Psicologia da USP, 2013.Disponível:

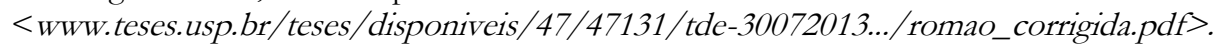
${ }^{54}$ MAFFESOLI, Michel. Comunicação sem fim. In: MARTINS, Francisco Menezes; SILVA (Orgs.), Juremir Machado da. A Genealogia do Virtual: comunicação, cultura e tecnologias do imaginário. Porto Alegre: Sulinas, 2004. p.24.

55 MAFFESOLI, Michel. Comunicação sem fim. In: MARTINS, Francisco Menezes; SILVA (Orgs.), Juremir Machado da. A Genealogia do Virtual: comunicação, cultura e tecnologias do imaginário. Porto Alegre: Sulinas, 2004. p. 21/22.
} 
do contemporâneo utiliza a escala de comunicação para assegurar, formar e relatar os enunciados, utilizando aqui uma categoria foucaultiana. Veja ainda, "a comunicação antes de tudo, remete ao estar junto; à informação, ao utilitário" 56 . Não há dúvida de um feixe relacional de poderes que servem à formação do arquivo e operam nas estruturas de formas de vida contemporâneas.

Mas as análises acerca do alcance desses feixes de informação e os reflexos na ordenação das formas de vida ainda suscitam distinções regionais, o que deve, certo modo, ser incluído no nosso exercício de reflexão: No brasil, muito mais que na França, os jornais (informação) seduzem microgrupos. Primeiro são jornais regionais, mesmo os de alcance nacional, como Folha de S Paulo, O Estado de S Paulo, O Globo e Jornal do Brasil, conservam marcas de inserção regional muito fortes ${ }^{57}$.

O perigoso nesse novo status de mundo é que a informação anunciada não veicula saberes em reflexão, mas veicula poderes que gerenciam verdade e esse fato pode desencadear ações absolutamente perversas no campo social o que contraria uma ótica garantista de aplicação dos saberes penais como Ferrajoli lembra ao mencionar o caráter de civilidade do direito, "esse princípio fundamental de civilidade representa o fruto de uma opção garantista a favor da tutela da imunidade dos inocentes, ainda que ao custo da impunidade de algum culpado" $" 58$.

Sobre a informação Morin provoca, "Mas a informação, mesmo no sentido jornalístico da palavra, não é conhecimento, pois conhecimento é o resultado da organização da informação" "59. Há como equalizar a circulação dos enunciados de verdade no campo jornalístico policial sem criar

\footnotetext{
${ }^{56}$ MAFFESOLI, Michel. Comunicação sem fim. In: MARTINS, Francisco Menezes; SILVA (Orgs.), Juremir Machado da. A Genealogia do Virtual: comunicação, cultura e tecnologias do imaginário. Porto Alegre: Sulinas, 2004. p. 22.

57 MAFFESOLI, Michel. Comunicação sem fim. In: MARTINS, Francisco Menezes; SILVA (Orgs.), Juremir Machado da. A Genealogia do Virtual: comunicação, cultura e tecnologias do imaginário. Porto Alegre: Sulinas, 2004. p.22.

${ }^{58}$ FERRAJOLI, Luigi. Direito e razão. 6. ed. São Paulo: Revista dos tribunais, 2002. p.414.

${ }^{59}$ MORIN, Edgar. A comunicação pelo meio (teoria complexa da comunicação). In: MARTINS, Francisco Menezes; SILVA Juremir Machado da (Org.), A Genealogia do Virtual: comunicação, cultura e tecnologias do imaginário. Porto Alegre: Sulinas, 2004. p.12.
} 
Revista da Faculdade Mineira de Direito | v.21 N.41 105

interfaces na atuação dos elementos do sistema penal? Talvez nesse ponto seja imperioso ampliar a zona de observação dos elementos que compõem o campo penal e criminológico.

\section{Conclusão}

Os casos elencados acima e as pequenas narrativas provenientes dos programas de jornalismo policial não figuraram no presente trabalho em vão, a rigor pretendeu-se demonstrar que tais narrativas compõem hoje, também, o campo criminal e não podem simplesmente serem descartadas de avaliação no processo de leitura acadêmica da esfera criminal. Como um ponto de verificação dos objetivos indicados na ordem metodológica proponho o olhar para a participação dos profissionais do jornalismo policial como Datena, Sheherazade, Marcelo Rezende e Caco Barcellos no debate acerca da legislação sobre a maioridade penal, nesse ponto acrescer que não se trata das "opiniões" veiculadas em redes regionais e nacionais ao grande público, mas do convite formal formulada pela Câmara de Deputados Federais para ouvir tais profissionais na qualidade de pessoas com expertise no tema.

Nas palavras do Presidente da Comissão que debate a PEC 171/93: "Todos eles são formadores de opinião e todos eles, nos seus programas, nas suas matérias, sempre trazem a discussão da redução da maioridade penal. Como eles conhecem a realidade, entendo que seria bom trazer a opinião deles sobre o tema na comissão", afirmou seu presidente, deputado André Moura (PSC-SE). ${ }^{\circ 0}$

A partir desse episódio pode-se indicar como conclusão e resposta ao primeiro objetivo que o jornalismo policial ao formular enunciados criminológicos e veicular um conjunto de saberes com valor de verdade penetra nos espaços de poder da construção formal dos enunciados penais. Nesse quesito, ainda cabe destaque ao teor do enunciado criminal

${ }^{60}$ A Comissão Especial da Câmara dos Deputados designada para discutir a PEC 171/93, que propõe a redução da maioridade penal de 18 para 16 anos, convocará os jornalistas Marcelo Rezende (TV Record), José Luiz Datena (Bandeirantes), Rachel Sheherazade (SBT) e Caco Barcellos (Globo) para uma audiência pública sobre o tema. O convite foi aprovado nesta quarta-feira 29.04. O link para acessar a notícia encontra-se elencado nas referências. 
Revista da Faculdade Mineira de Direito | v.21 N.41| 106

produzido, posto que as informações que circulam possuem como alvo principal os sujeitos delinquentes, atuando numa verdadeira escala de produção dos corpos infames do sistema sócio jurídico.

$\mathrm{Na}$ conclusão cabe ainda fazer um aceno à figura do criminoso e sua relação com a mídia. E o criminoso, enfim, como se apresenta na nova ordem dos enunciados policiais? Aqui, anote-se, o criminoso é fundamental para essa circularidade de saberes e poderes, mais que qualquer outro elemento dessa arquivologia, ele é o substrato biopolítico de primeira ordem. O Infame, monstro, anormal, criminoso mirim ou adulto, pouco importa, ele é essencial.

O criminoso é necessário para a mídia, é vital para circular um conjunto de emoções e abrir espaços a certas técnicas de controle, e a exposição que a mídia faz do criminoso é essencial aos mecanismos de Estado, às razões de governamentalidade, pois sem empreenderem maiores esforços conseguem um discurso legitimante de práticas excludentes. Como já advertia o filósofo de Poitiers "Com efeito, a opinião e a imprensa precisam do criminoso. É a ele que se vai odiar, é para ele que irão as paixões, é para ele que se pedirão a pena e o esquecimento" ${ }^{\prime \prime}$.

Como resultado e resposta ao segundo questionamento, ou seja, em relação à interferência dos enunciados criminológicos através do jornalismo policial e os dispositivos jurídicos é possível concluir pela sua ocorrência. Nesse prisma algo interessante podemos indicar a partir da análise arqueogenealógica de matriz foucaultiana. Lembra Foucault, "esse mesmo corpo que é tão visível, é afastado, captado por uma espécie de invisibilidade da qual jamais posso desvencilhá-lo" ${ }^{62}$. Nesse sentido, o espaço das visibilidades exaustivamente trabalhado na esfera do jornalismo policial é substituído pela invisibilidade biopolítica no espaço do judiciário, essa inversão observa uma lógica funcional: para produzir corpos infames é necessário explorar as imagens negativas, desenhar contornos monstruosos, construir sujeitos indesejáveis e repulsivos, logo explorar o dizível e o visível são artefatos necessários. É preciso ver. Noutra ponta, para excluir sujeitos

${ }^{61}$ Doravante a segurança está acima da lei. In: FOUCAULT, Michel. Ditos e escritos VIII - Segurança, penalidade e prisão. Rio de Janeiro: Forense Universitária, 2012. p.118.

${ }^{62}$ FOUCAULT, Michel. O corpo utópico - as heterotopias. São Paulo: n1 Edições, edição bilíngue: português/francês, 2013. p.10. 
Revista da Faculdade Mineira de Direito | v.21 N.41 107

do sistema social é necessário dotá-los de invisibilidade, o espaço jurídico vai veicular o conjunto de direitos, nesse aspecto é estratégico cortar a fala e a visibilidade para realizar mais legitimamente a recusa de direitos e conferir grau de exclusão ao conjunto dos sujeitos criminosos. Em parte, é possível pensar os enunciados criminológicos do jornalismo policial como reforço ao discurso do direito penal punitivista e à política de encarceramento como resposta ao par crime-criminoso.

FROM THE FORMATION OF THE CRIMINOLOGICAL

STATEMENT TO THE PRODUCTION OF THE INFAMES IN THE WAY OF POLICE JOURNALISM: RESONANCES IN THE SOCIOJURIDICAL FIELD

\section{ABSTRACT}

The research focused on analytically analyzing aspects of the criminological sphere from the philosophical matrix of Michel Foucault. In central terms the text addresses the question of the formation and recognition of the figure of the criminal through the police and the interface in the criminal social and legal sphere. The trajectory of the text sought to identify the production of "infamous bodies" in criminological knowledge-power structures. In this order, the problem faced in the work consists in observing the process of formation of the "criminological power enunciation" from the narratives of police journalism.

Keywords: Criminological statement; police journalism; infamous bodies.

\section{Referências}

AZEVEDO, R.C.S.; RAMOS, F.R.S. Arqueologia e genealogia como opções metodológicas de pesquisa na enfermagem. Revista Bras Enferm, Brasilia (DF) 2003 maio/jun;56(3):288-291. Disponível em: <http://www.scielo.br/pdf/reben/v56n3/a14v56n3.pdf> 
Revista da Faculdade Mineira de Direito | v.21 N.41 108

BARATTA, Alessandro. Criminologia Crítica e Crítica do Direito Penal: Introdução à sociologia do direito penal. Rio de Janeiro: Editora Revan, 2013.

BRANDÃO, Cláudio. Tipicidade penal: dos elementos da dogmática ao giro conceitual do método entimemático. Coimbra: Almedina, 2012.

BERT, Jean-François. Pensar com Michel Foucault. São Paulo: Ed. Parábola, 2013.

BUTLER, Judith. Quadros de guerra: quando a vida é passível de luto. Rio de Janeiro: Civilização brasileira, 2015.

CHAVES, João. O problema do direito novo em Michel Foucault: entre a resistência e o fora. Recife: Universidade Federal de Pernambuco (Dissertação de Mestrado), 2006.

DELEUZE, Gilles. Foucault. $6^{a}$ ed. São Paulo: Brasiliense, 2006.

DERRIDA, Jacques. Força de Lei. São Paulo: Martins Fontes, 2007

DÍAZ, Esther. A filosofia de Michel Foucault. $1^{a}$ Ed. São Paulo: Editora Unesp, 2012.

ERIBON, Didier. Michel Foucault - uma biografia. Trad. de Hildegard Feist. São Paulo: Companhia das Letras, 1990.

FERRAJOLI, Luigi. Direito e razão. 6. ed. São Paulo: Revista dos tribunais, 2002.

FOUCAULT, Michel. A arqueologia do saber. Tradução de Luiz Felipe Baeta Neves. Revisão de Lígia Vassalo. Petrópolis: Vozes, 1972.

As palavras e as coisas. $6^{a}$ ed. São Paulo: Martins Fontes, 1992.

Surveiller et punir. Gallimard, 1993. 
Revista da Faculdade Mineira de Direito | v.21 N.41 109

. Dits et écrits 2 (1976-1988). Coleção Quarto, Gallimard, 1995. . A ordem do discurso. $6^{a}$ ed. São Paulo: Loyola, 2000.

Ditos \& escritos, vol. II. Rio de Janeiro, Forense Universitária, 2000b.

. Em Defesa da Sociedade. São Paulo, Martins Fontes, 2002.

. Vigiar e punir. $21^{a}$ ed. Trad. de Raquel Ramalhete. São Paulo: Vozes, 2002b.

. A filosofia analítica da política. In:___. Ditos e Escritos V Ética, sexualidade, política.Rio de Janeiro: Forense Universitária, 2004.

. História da sexualidade, vol.1, A vontade de Saber. Rio de Janeiro: Graal, $17^{\mathrm{a}}$ edição, 2006.

. Doravante a segurança está acima da lei. In: Ditos e escritos VIII - Segurança, penalidade e prisão. Rio de Janeiro: Forense Universitária, 2012.

. O corpo utópico - as heterotopias. São Paulo: n1 Edições, edição bilíngue: português/francês, 2013.

GIORGIO, Raffaele De. Direito penal e teoria da ação entre hermenêutica e funcionalismo. Veredas do direito, v.3, jul/dez 2004, Belo Horizonte:Escola Superior Dom Helder, 2004.

KOBBÉ, Ulrich. Verbrechen und Strafen: Beccaria con Foucault : eine Re-Lektüre rechts- und gesellschaftsphilosophischer Grundlagen. Psychologie \& Gesellschaftskritik, v.34, n.3. Erlangen: Pabst, 2010.

KRASMANN, Susanne. Von der Disziplin zur Sicherheit. Foucault und die Kriminologie. Foucaults Machtanalytik und Soziale Arbeit. Roland 
Revista da Faculdade Mineira de Direito | v.21 N.41 110

Anhorn, Frank Bettinger, Johannes Stehr (Hrsg.), Wiesbaden: VS Verlag, 2007.

KUNZ, Karl-Ludwig. Zur Symbolik des Strafrechts. Verbrechen, Strafe, Resozialisierung. Festschrift für Heinz Schöch zum 70. Geburtstag. Dieter Dölling, Bert Götting, Bernd-Dieter Meier, Torsten Verrel (Hgrs.). Berlin: de Gruyter, 2010

LIPOVETSKY, Gilles. Sedução, publicidade e pós-modernidade. In: LOPES,Jr; limite penal e crise de identidade e ordem pública: fundamento para prisão preventiva. Disponível em: $<$ http://www.conjur.com.br/2015-fev-06 >

LOPES JR, Aury; ROSA, Alexandre Moraes da. Processo penal no limite. Empório do Direito, 2015.

MAFFESOLI, Michel. Comunicação sem fim. In: MARTINS, Francisco Menezes; SILVA (Orgs.), Juremir Machado da. A Genealogia do Virtual: comunicação, cultura e tecnologias do imaginário. Porto Alegre: Sulinas, 2004.

MORIN, Edgar. A comunicação pelo meio (teoria complexa da comunicação). In: MARTINS, Francisco Menezes; SILVA Juremir Machado da (Org.), A Genealogia do Virtual: comunicação, cultura e tecnologias do imaginário. Porto Alegre: Sulinas, 2004.

PELBART, Peter Pál. Vida Capital: ensaios de biopolítica. São Paulo : Iluminuras, 2009.

PELBART, Peter Pál. Vida e Morte em Contexto de Dominação

Biopolítica. Conferência proferida no dia 3 de outubro de 2008 no Ciclo "O Fundamentalismo Contemporâneo em Questão", organizado pelo Instituto de Estudos Avançados (IEA) da USP. Disponível em: http://www.iea.usp.br/publicacoes/textos/pelbartdominacaobiopolitica.p df 
Revista da Faculdade Mineira de Direito | v.21 N.41| 111

PELLER, Mariela. Judith Butler y Ernesto Laclau. Reflexiones sobre la subjetividad, la historia y la política. XXVII Congreso de la Asociación Latinoamericana de Sociología. VIII Jornadas de Sociología de la Universidad de Buenos Aires. Asociación Latinoamericana de Sociología, Buenos Aires, 2009.

REVEL, Judith. Michel Foucault - conceitos essenciais. São Carlos: Claraluz, 2005.

ROMÃO, Davi Mamblona Marques. "Jornalismo Policial: indústria cultural e violência". Dissertação de Mestrado apresentada no Programa de Pós Graduação em Psicologia da USP, 2013.Disponível:www.teses.usp.br/teses/disponiveis/47/47131/tde30072013.../romao_corrigida.pdf

SANGUINÉ, Odone. A inconstitucionalidade do clamor público como fundamento da prisão preventiva. Revista de estudos criminais, n. 10. Porto Alegre: Nota dez. p.113-119, 2003.

ZAFFARONI, Eugenio Raúl. En torno de la cuestión penal. Buenos Aires: Editorial B de F, 2005.

ZAFFARONI, Eugenio Raúl ET al. Direito penal brasileiro: teoria do delito, introdução histórica e metodológica, ação e tipicidade. Rio de Janeiro: Revan, 2010.

Bronca Pesada com Cardinot (Trechos). TV Jornal Digital. Recife, 07 jul. 2011. Disponível em:

$<$ https://www.youtube.com/watch?v=qyBsgDXDOKs $>$. Acesso em: 24 jun. 2017.

Jovem é liberado após confessar nove assaltos em audiência de custódia. TV Jornal. Reportagem Suelen Brainer. Recife, 28 jun. 2017. Disponível em: <http://tvjornal.ne10.uol.com.br/videos/2017/06/28/jovem-eliberado-apos-confessar-nove-assaltos-em-audiencia-de-custodia.php $>$. Acesso em: 30 jun. 2017. 
Revista da Faculdade Mineira de Direito | v.21 N.41 $\mid 112$

Para discutir redução da maioridade penal, Câmara convida Datena, Sheherazade e Marcelo Rezende. Revista Fórum. 24 abr. 2015. Disponível em: <http://www.revistaforum.com.br/2015/04/29/reducaomaioridade-penal/>. Acesso em: 24 jun. 2017. 